\title{
In vitro and in vivo effect of Eurycoma longifolia root extract on UDP-glucuronosyltransferase activity
}

\author{
Purwantiningsih Purwantiningsih ${ }^{1}$, Abas Hj Hussin ${ }^{2}$, Sabariah Ismail ${ }^{3}$, Kit Lam Chan ${ }^{2}$ \\ ${ }^{1}$ Faculty of Pharmacy, Universitas Gadjah Mada, Yogyakarta, Indonesia. \\ ${ }^{2}$ School of Pharmaceutical Sciences, Universiti Sains Malaysia, Pulau Pinang, Malaysia. \\ ${ }^{3}$ Drug Research Centre, Universiti Sains Malaysia, Pulau Pinang, Malaysia.
}

\begin{tabular}{|c|c|}
\hline ARTICLE INFO & ABSTRACT \\
\hline $\begin{array}{l}\text { Received on: } 06 / 03 / 2019 \\
\text { Accepted on: } 20 / 06 / 2019 \\
\text { Available online: 01/09/2019 }\end{array}$ & $\begin{array}{l}\text { The aim of this research was to evaluate the effects of Eurycoma longifolia root extract (ELE) on enzymes activity in the } \\
\text { phase II drug metabolism on Sprague-Dawley (SD) rats, especially on uridine } 5 \text { '-diphospho-glucuronosyltransferase } \\
\text { (UGT) activity, in vivo and in vitro. The UGT assay was performed as follows: for the in vivo study, the male SD } \\
\text { rats were treated with ELE at doses ranging from } 5 \text { to } 1,000 \mathrm{mg} / \mathrm{kg} \text { b.w. and } 5,25 \text {, and } 50 \mathrm{mg} / \mathrm{kg} \text { b.w for acute }\end{array}$ \\
\hline $\begin{array}{l}\text { Key words: } \\
\text { Eurycoma longifolia, phase } \\
\text { II drug metabolism, UGT } \\
\text { enzyme activity. }\end{array}$ & $\begin{array}{l}\text { and sub-acute study, respectively. The ELE concentrations of } 0.01 \text { to } 1,000 \mu \mathrm{g} / \mathrm{ml} \text { were used for in vitro study. The } \\
\text { p-nitrophenol (pNP) that consumed in the glucuronidation process reflected the UGT activity and was calculated using } \\
\text { standard curve of pNP. UGT enzyme activity was inhibited significantly }(p<0.01) \text { by ELE extract in the male rat for } \\
\text { both acute and sub-acute experiments. ELE extract decreased the enzyme activity significantly }(p<0.01) \text {, at all the } \\
\text { concentrations tested in the in vitro experiment when compared to the negative control group. ELE had a lower activity } \\
\text { (the IC } 50 \text { of } 0.74 \mu \mathrm{g} / \mathrm{ml} \text { ) as compared to Na diclofenac (positive control) with an IC50 of } 0.17 \mu \mathrm{g} / \mathrm{ml} \text {. Eurycoma } \\
\text { longifolia decreased the UGT enzyme activity significantly }(p<0.01) \text {, both for in vivo and in vitro study. }\end{array}$ \\
\hline
\end{tabular}

\section{INTRODUCTION}

Herbal medicines have been used for a long time (Zhang et al., 2005) and the market has been rapidly growing. The usage of herbal preparations is widespread, especially in China, South and Central America, Africa, Indonesia, India and Pacific Islands, United States, Suriname, Ghana, and Peru (Barnes et al., 2008; Bhattaram et al., 2002; Bussmann and Sharon, 2009; Van-Andel and Myren, 2012; Van-Andel and Carvalheiro, 2013).

Herbal-drug interactions can be defined as pharmacological or clinical responses to joint use of traditional drugs or pharmaceutical preparations and herbal products (Brazier and Levine, 2003). Using herbal medicines that are often coadministered with prescribed drugs could raise the potential of herb-drug interactions (Zhou et al., 2004). The belief of society

\footnotetext{
${ }^{*}$ Corresponding Author

Purwantiningsih Purwantiningsih, Faculty of Pharmacy, Universitas Gadjah Mada, Yogyakarta, Indonesia.

E-mail:purwantiningsih@ugm.ac.id
}

is that herbal drugs are natural, and therefore safe for consumption have resulted in many herbal products on sale in the market (Newall et al., 1996; Zhang et al., 2005). However, there are many possibilities that any substance in the herbal drug may influence the bioavailability of drugs or the other substances by inducing drug metabolism on phase I or II, and affect the therapeutic effect. Many published reports related to the interaction of herbal medicines, side effects of herbal medicines, and also the ability of herbal medicines to influence therapeutic effects of prescribed drugs (Ernst, 2002; Low and Tan, 2007; Mills et al., 2005). The concurrent use of herbal medicines, with synthetic drugs, can mimic, synergistic or contradict the effects of the drugs (FughBerman, 2000), where the interactions may cause some serious clinical consequences (Izzo and Ernst, 2001; Saxena et al., 2008; Zhou et al., 2004). Many experiments have been done to reveal the influence of herbal preparations on drug metabolism, especially on UDP-glucuronosyltransferase (UGT) and glutathione-Stransferase activities.

Thus, studies about the effect of herbal medicines on pharmacological profile of drug involving the phase I or phase II of 
drug metabolism, pharmacokinetics, and herbal-drug interaction studies will give the important impact for the rational usage of herbal remedies (Zhang et al., 2005).

Eurycoma longifolia is one of the common plants in Asia, and was used as herbal-drug. The plant is known as "Tongkat Ali" in Malaysia and the society use the root as an aphrodisiac (Chan et al., 1998). The root contains several classes of chemical constituents, such as alkaloids, triterpenes, squalene derivatives, quassinoids, and biphenylneolignan (Chan et al., 2004; Itokawa et al., 1992; Kanchanapoom et al., 2001; Morita et al., 1992; 1993). Based on previous study, E. longifolia root extract (ELE) influenced the phase I aminopyrine and rosiglitazone metabolism in rat hepatocytes (Purwantiningsih et al., 2010; 2011). The other studies showed that the ELE affected aminopyrin and rosiglitazone metabolism at the molecular level (Purwantiningsih et al., 2012; 2015), while the eurycomanone (a marker compound of ELE) could inhibit the human cytochromes P450 (Purwantiningsih et al., 2014). The present study evaluated the effect of ELE on phase II drug metabolism, especially on UGT enzymes activity.

\section{MATERIALS AND METHODS}

\section{Materials}

Eurycoma longifolia root extract (ELE) was extracted and standardized in School of Pharmaceutical Sciences (Department of Pharmaceutical Chemistry), Universiti Sains Malaysia (USM), according to the protocol that was described previously (Chan et al., 1998). The roots of E. longifolia were collected from District of Teluk Bahang in Penang, Malaysia, whereas the voucher specimen was deposited at the Penang Botanical Garden, Malaysia with Reference No. 785-117. The roots powdered were weighed of $2 \mathrm{~kg}$ and were extracted repeatedly at room temperature (six times for 2 weeks) with aqueous ethanol (1:1). All the aqueous ethanol extracts were pulled and evaporated to get the dry extract with $2.8 \%$ yield. The extract was standardized based on the eurycomanone contain as a standard compound. The standardized extract contains eurycomanone of $19.6 \%$.

BioRad protein assay kit was purchased from Hercules, CA, while CDNB (1-chloro-2,4-dinitrobenzene), Glutathione reduced form, Glycerol, p-Nitrophenol, Tris-HCl, UDPGA (Uridine 5'-diphosphoglucoronic acid) and Sodium diclofenac from Sigma Chemicals Co, USA. UK Diethyl ether was obtained from BDH Laboratory Supplies, UK, and Magnesium chloride was purchased from ChemAR, System, Malaysia. Disodium hydrogen phosphate and Potassium chloride were purchased from R \& M Chemicals, UK, while Potassium dihydrogen orthophosphate was obtained from Ajax Chemicals, Australia. Sodium hydroxide was obtained from J \& J Laboratory Chemicals, Austria, Tannic acid from HmbG Chemicals, Malaysia, Trichloroacetic acid from Fisher Scientific, USA, and Triton X-100 from ICN Biomedicals, Inc, USA. Standard food pellets were purchased from Gold Coin ${ }^{\circledR}$, Penang, Malaysia.

\section{Experimental animals}

The male rats from Sprague-Dawley (SD) strain, age of 20-24 months and the weight are about $400 \pm 50 \mathrm{~g}$ were used to investigate the E. longifolia effect on UGT enzyme activity. The rats were separated into two groups, one group for in vitro study and another group for in vivo study. In the in vivo study, the rats were divided into two groups, namely, acute and sub-acute that will be treated for 1 and 14-day treatment, respectively.

Acute group was separated into six treated groups and control group. The rats in the control group $(n=6)$ were administered with the vehicle (distilled water), while the treated groups ( $n=6$ in each group) the rats were treated with ELE at doses $5,25,50,100,500$, and $1,000 \mathrm{mg} / \mathrm{kg} \mathrm{b}$. w. (body weight). The rats in the sub-acute study were divided into three treated groups and one group for control. The control group received distilled water, while the treated groups were fed ELE single dose daily, orally, at different doses $(5,25$, and $50 \mathrm{mg} / \mathrm{kg}$ b.w.). The ELE concentrations ranging from 0.01 to $1,000 \mu \mathrm{g} / \mathrm{ml}$ were used for in vitro study.

All the rats were given food and water ad libitum. The research protocol has been submitted to the Ethics Committee at the School of Pharmaceutical Sciences, USM, Malaysia with Ref. Number of USM/PPSF/50 (066) Jld.2.

\section{Preparation of microsomal and cytosolic fractions from rats liver}

The rats were anesthetized using diethyl ether in a jar for 5 minutes. They were pinched the hind paws to confirm that they did not respond to pain. The rat was then cut at the abdomen for preparing the perfusion and the liver was taken out. Then, the liver was rinsed in incubation medium and soaked in ice-cold potassium phosphate buffer $(67 \mathrm{mM})$ with $1.15 \%$ potassium chloride $(\mathrm{pH}$ 7.4). The liver was dried using a tissue and weighed. The liver was separated for a certain amount and was added the ice-cold of potassium phosphate buffer with $\mathrm{KCl}$ (three times of the weight) and was then homogenized using a Potter-Elvehjem at $4^{\circ} \mathrm{C}$.

The homogenates were then pooled in a glass beaker. After this, the homogenate was filled into micro-centrifuge tubes $\left(\right.$ Optiseal $\left.{ }^{\mathrm{TM}}\right)$, was then centrifuged for 20 minutes $\left(4^{\circ} \mathrm{C}\right)$ at $12,500 \times \mathrm{g}$ to get the fraction. The supernatant was removed and centrifuged for 60 minutes $\left(4^{\circ} \mathrm{C}\right)$ at $100,000 \times \mathrm{g}$ in a refrigerated ultra-centrifuge (Beckman Coulter, Inc., USA). The supernatant (cytosolic fraction) was separated from the precipitate (microsomal fraction). The precipitate fraction was added with phosphate buffer (pH 7.4) containing potassium chloride $(1.15 \%)$ and glycerol $(20 \%)$, was homogenized and was then filled into microcentrifuge tubes. All the fractions (the cytosolic and microsomal fractions) were stored in freezer $\left(-70^{\circ} \mathrm{C}\right)$ until used. Protein concentrations in all the fractions were assayed using the BioRad protein kit. For the UGT assay, it was used the microsomes fraction, while the cytosolic fraction was used for another experiment.

\section{UGT assay using rat liver microsomes}

The UGT assay was performed using a method that was described before by Bock \& Kohle (2004).

\section{Preparation of the standard curve of p-nitrophenol (pNP)}

The 5-mM p-nitrophenol solution (stock solution) was prepared by dissolving it in distilled water to make a standard curve of p-nitrophenol. Then, it was made a serial dilution with concentration ranged 0.2 to $1 \mathrm{mM}$ from the stock solution in separate tubes. The reaction was begun by adding $25 \mu \mathrm{l}$ of $1-\mathrm{M}$ Tris- $\mathrm{HCl}(\mathrm{pH} 7.4)$ and $\mathrm{MgCl}_{2}(50 \mathrm{mM})$, respectively. The mixture was pre-incubated at $37^{\circ} \mathrm{C}$ in the water bath shaker for 5 minutes and followed by the addition $25 \mu \mathrm{l}$ of $30 \mathrm{mM}$ UDPGA. In the blank 
group, p-nitrophenol was replaced with distilled water $(200 \mu \mathrm{l})$ and each set of reading was made in triplicate $(n=3)$. The reaction mixture was incubated at $37^{\circ} \mathrm{C}$ for 15 minutes and was then terminated with the addition $1 \mathrm{ml}$ of ice-cooled trichloroacetic acid $(5 \%)$ for protein precipitation. The solutions were centrifuged for 5 minutes at 4,000 rpm using Universal-320R ${ }^{\circledR}$ centrifuge machine. The supernatant $(200 \mu \mathrm{l})$ was removed and filled into 96-well plate. Fifty microliter of $\mathrm{NaOH}(5 \mathrm{M})$ was added to configurate the color of the mixture and was then incubated for 10 minutes at room temperature. The absorbance was recorded using a Powerwave $\mathrm{X}-340^{\circledR}$ microplate reader at $405 \mathrm{~nm}$. The standard curve was performed by plotting the absorbance of standard solution at 405 $\mathrm{nm}$ versus p-nitrophenol concentration $(\mathrm{mM})$.

In vitro effect of $E$. longifolia extract on the uridine 5'-diphospho-glucuronosyltransferase (UGT) activity in male SD rat using liver microsomes

UGT activity assay was performed into three groups, test group, blank group, and control group. The method for the assay was done as follows: the combination of 1-M Tris- $\mathrm{HCl}$ (pH 7.4), Triton X-100 (0.25\% w/v), and $\mathrm{MgCl}_{2}(50 \mathrm{mM}), 25 \mu \mathrm{l}$ of each was filled into microcentrifuge tubes and was added with 5 -mM p-nitrophenol solution as substrate $(25 \mu \mathrm{l})$. Then, $50 \mu \mathrm{l}$ of microsomes $(1.88 \mathrm{mg} / \mathrm{ml})$ was added. A volume of distilled water was added to make the total final volume of $250 \mu \mathrm{l}$. The ELE solution $(25 \mu \mathrm{l})$ in distilled water was added into the tubes in the different concentration $(0$ to $10 \mathrm{mg} / \mathrm{ml})$ to get the ELE final concentration of 0 to $1,000 \mu \mathrm{g} / \mathrm{ml}$. Pre-incubation was done at temperature $37^{\circ} \mathrm{C}$ for 5 minutes in a water-bath shaker, then a volume of $25 \mu 1$ of $30 \mathrm{mM}$ UDPGA was added, and was followed with incubation at the same temperature for 15 minutes. The assay was made in duplicate for each set and was made in triplicate for each reading. A volume of 1 $\mathrm{ml}$ of ice-cooled TCA $(5 \%)$ was added to stop the reaction and the tubes were centrifuged for 5 minutes at 4,000 rpm. The supernatant $(200 \mu \mathrm{l})$ was taken out and the absorbance was measured using a microplate reader after incubation with $\mathrm{NaOH}(50 \mu \mathrm{l} ; 5 \mathrm{M})$ for 10 minutes at $27^{\circ} \mathrm{C}$. In the blank group, the rat liver microsomes were heated for 10 minutes at $60^{\circ} \mathrm{C}$ for denaturation process and the ELE solution was changed with distilled water in the control group. Nadiclofenac was used as a positive control.

In vivo effect of $E$. longifolia extract on the uridine 5'-diphospho-glucuronosyltransferase (UGT) activity in male SD rat using liver microsomes

The rats for this experiment were divided into two groups, for acute study (1-day treatment) and sub-acute study (14day treatment). The assay was performed by following the assay method for the in vitro experiments.

\section{The calculation of the uridine 5'-diphospho- glucuronosyltransferase (UGT) activity}

The UGT activity was calculated based on the amount of pNP consumed in the glucuronidation process, used the Equation (1). The amount of pNP was determined from the sample absorbance by using the standard curve of pNP.

UGT activity: $\frac{\mathrm{pNP} \text { concentration, } \mathrm{mM}(\text { Blank })-\mathrm{pNP} \text { concentration, } \mathrm{mM}(\text { Test })}{\text { Incubation time, minute } \times \text { concentration of the used protein, } \mathrm{mg} / \mathrm{ml}}$
The time of incubation was 15 minutes and the final protein concentration was $0.38 \mathrm{mg} / \mathrm{ml}$. The assay expressed the UGT activity as nmol $\mathrm{pNP}$ consumed $/ \mathrm{min} / \mathrm{mg}$ protein, then was compared to control group to get the $\%$ activity.

\section{Data analysis}

The initial data was the absorbance values of each sample, then was calculated the percentage of activity of the UGT enzyme. The data were analyzed using statistical analysis of the $t$-test to compare with the control group. Data are considered to have a significant difference if the $p$ value is $<0.05$ or smaller. After that, the inhibition value (IC-50) was calculated using a linear regression equation from the relationship curve of the concentration of the sample and the percentage of activity.

\section{RESULTS AND DISCUSSION}

\section{UGT activity assay}

Protein concentration was determined before microsomes fraction was used to do the UGT activity assay and was calculated using bovine serum albumin standard curve. The linear regression of standard curve was $Y=0.001 X+0.017$ and the $R^{2}$ value was 0.993 . The results of the determination of microsomes protein levels are shown in Table 1.

The amount of pNP consumed in glucuronidation process was determined using standard curve of $\mathrm{pNP}$. The linear regression of pNP standard curve was $Y=2.547 X+0.006$, while the variation coefficient value $\left(R^{2}\right)$ was 0.999 . Based on the optimization process, the incubation time was 15 minutes while the final protein concentration was $0.38 \mathrm{mg} / \mathrm{ml}$.

In vitro effect of $E$. longifolia extract on the uridine 5'-diphospho-glucuronosyltransferase (UGT) activity in male SD rat using liver microsome

The effective concentration that produced a $50 \%$ activity (IC-50) was calculated using curve of the relationship between ELE concentrations to percentage of activity. The IC-50 value was

Table 1. Protein concentration in the liver microsomes fraction for in vitro, acute, and sub-acute study of UGT activity assay.

\begin{tabular}{|c|c|}
\hline Group of rats & Protein concentration in $\mathrm{mg} / \mathrm{ml}($ mean $\pm \mathrm{SD} ; n=6)$ \\
\hline In vitro study & $102.63 \pm 3.95$ \\
\hline \multicolumn{2}{|l|}{ Acute study } \\
\hline Control & $65.40 \pm 0.50$ \\
\hline Dose I ( $5 \mathrm{mg} / \mathrm{kg}$ b.w.) & $77.10 \pm 3.52$ \\
\hline Dose II ( $25 \mathrm{mg} / \mathrm{kg}$ b.w.) & $70.47 \pm 1.21$ \\
\hline Dose III (50 mg/kg b.w.) & $62.46 \pm 0.06$ \\
\hline Dose IV (100 mg/kg b.w.) & $99.33 \pm 0.25$ \\
\hline Dose V (500 mg/kg b.w.) & $75.53 \pm 1.41$ \\
\hline Dose VI (1000 mg/kg b.w.) & $87.06 \pm 2.03$ \\
\hline \multicolumn{2}{|l|}{ Sub-acute study } \\
\hline Control & $61.33 \pm 0.81$ \\
\hline Dose I ( $5 \mathrm{mg} / \mathrm{kg}$ b.w.) & $57.76 \pm 0.06$ \\
\hline Dose II ( $25 \mathrm{mg} / \mathrm{kg}$ b.w.) & $82.53 \pm 1.95$ \\
\hline Dose III ( $50 \mathrm{mg} / \mathrm{kg}$ b.w.) & $62.73 \pm 2.15$ \\
\hline
\end{tabular}


compared to positive control to know the inhibition potency of ELE extract.

The effect of ELE on UGT activity was shown in Figure 1, all ELE concentrations tested ranging from 0.01 to $1,000 \mu \mathrm{g} / \mathrm{ml}$ decreased significantly the UGT activity. ELE inhibited significantly the UGT activity at the concentration 0.01 $\mu \mathrm{g} / \mathrm{ml}(p<0.01)$, on the other hand the ELE concentration from 0.1 to $1,000 \mu \mathrm{g} / \mathrm{ml}$ had a inhibition potency with the significant level of $99.9 \%$. Na-diclofenac was used as a positive control and showed an inhibition at all the concentrations tested ( 0.01 to 1,000 $\mu \mathrm{g} / \mathrm{ml})$ with the significant level of $99.9 \%$. The IC-50 value of ELE was $0.74 \mu \mathrm{g} / \mathrm{ml}$, while the Na-diclofenac had an IC-50 value of $0.17 \mu \mathrm{g} / \mathrm{ml}$. The result revealed that the inhibition potency of ELE was lower if compared to Na-diclofenac as positive control.

An-acute study the effect of $E$. longifolia extract on uridine 5'-diphospho-glucuronosyltransferase (UGT) activity in male SD rat liver microsomes

For acute study or 1 day in vivo treatment, the result was shown in Figure 2. The ELE had an effect on UGT activity in rat liver microsomes. It occurred a significant decreased $(p<0.01$ and $p<0.001)$ in all the treated groups as compared to control group at doses from 5 to $1,000 \mathrm{mg} / \mathrm{kg}$ b.w. Although the decrease is not proportional to the increase in dosage used, increased in three initial doses $(5,25$, and $50 \mathrm{mg} / \mathrm{kg}$ b.w.) then go up and get down in three doses thereafter $(100,500$, and 1,000 $\mathrm{mg} / \mathrm{kg} \mathrm{b.w.).}$

The Sub-acute study the effect of $E$. longifolia extract on uridine 5'-diphospho-glucuronosyltransferase (UGT) activity in male SD rat liver microsomes

For the sub-acute study, an ELE dose of 5, 25, and 50 $\mathrm{mg} / \mathrm{kg}$ b.w. were used. There was a significant decrease $(p<0.001)$ on UGT activity after the rats were treated with extract for 14 days when compared to the control group. But, increasing the dose of
ELE extract does not provide an increase in effect proportionally. The highest effect was reached at a dose of $25 \mathrm{mg} / \mathrm{kg} \mathrm{b.w}$. and followed by a dose of 50 then a dose of $5 \mathrm{mg} / \mathrm{kg}$ b.w. (Fig. 3). Therefore, the IC-50 in the in vivo study for both acute and subacute cannot be determined.

Glucuronidation is the most important conjugation reaction process and occurs widely in the process of life. The conjugation reaction involves UDP-glucuronosyltransferase enzymes (UGT). This experiment used liver microsomes fraction to determine the modulation effect of ELE on UGT activity. Many previous studies of UGT activity used liver microsomes fraction. The effect of some medicinal plants on UGT activity has been examined for both in vivo and in vitro studies and many papers have been published (Han et al., 2009; Ismail et al., 2010; Mahfoudh et al., 2009). Certain plants decreased UGT activity, while other plants increased the same activities.

ELE extract decreased UGT activity significantly in vitro, while in the in vivo study, the ELE decreased UGT activity both for acute (1-day treatment) or sub-acute (14-day treatment) studies. The sub-acute result was in agreement with a study by Han (2006). The results showed that the standardized methanol extract of Orthosiphon stamineus decreased UGT activity after 14 days of administration at a high dose in normal female SD rats but increased UGT activity after a single day of administration. Zhou et al. (2003) mentioned that the regulation of enzyme activity by an herb depends on the type of herb, dose, and route of administration, as well as the target organ and species.

UGT may be subject to induction and inhibition by drugs, xenobiotics, or a wide range of active ingredients derived from herbal plants. Natural active compounds, such as flavones and flavonones, can increase the UGT activity in rat liver (Hodex et al., 2002). One study showed that Morinda citrifolia (Noni) juice decreased UGT activity after 1-day treatment on rats (Mahfoudh et al., 2009). Another study reported that the extract of Andrographis

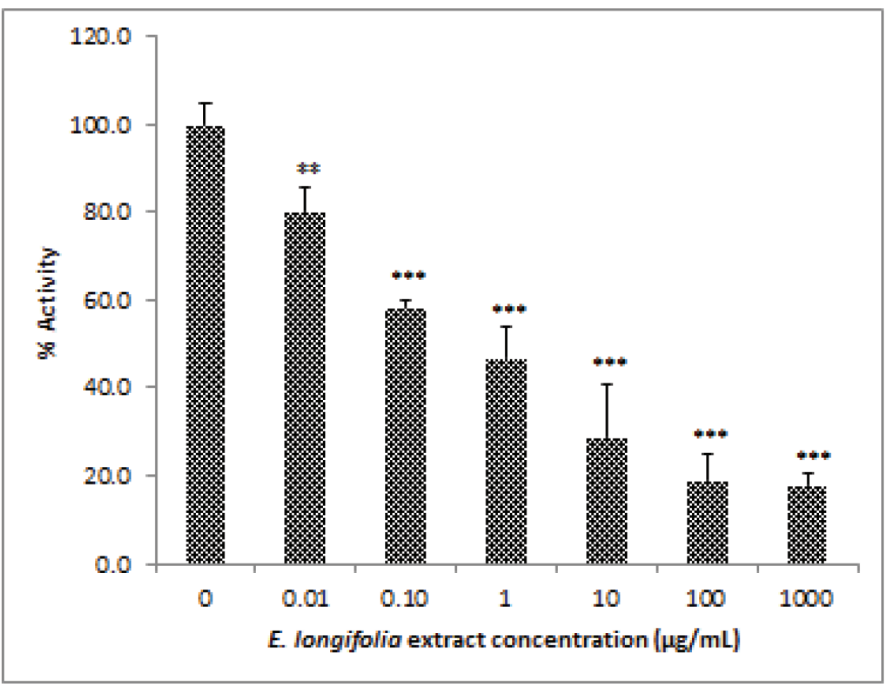

A

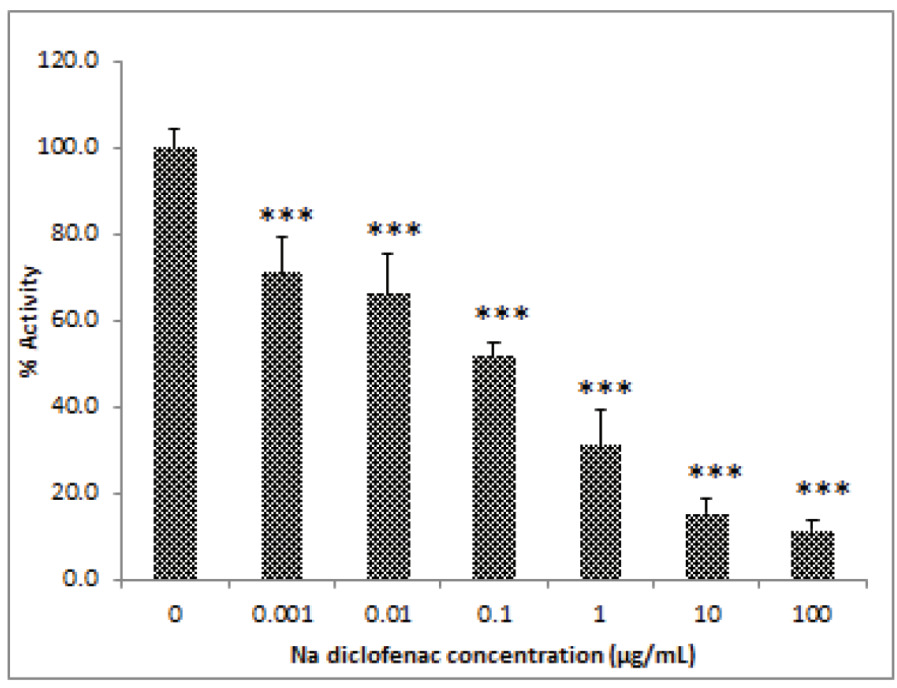

B

Figure 1. ELE had a lower activity in inhibition of UGT activity (A) if compared to Na diclofenac and (B) as a positive control. *p $<0.05,{ }^{* *}$ p $<0.01,{ }^{* * *} \mathrm{p}<0.001$ was significantly different if compared to control group. 


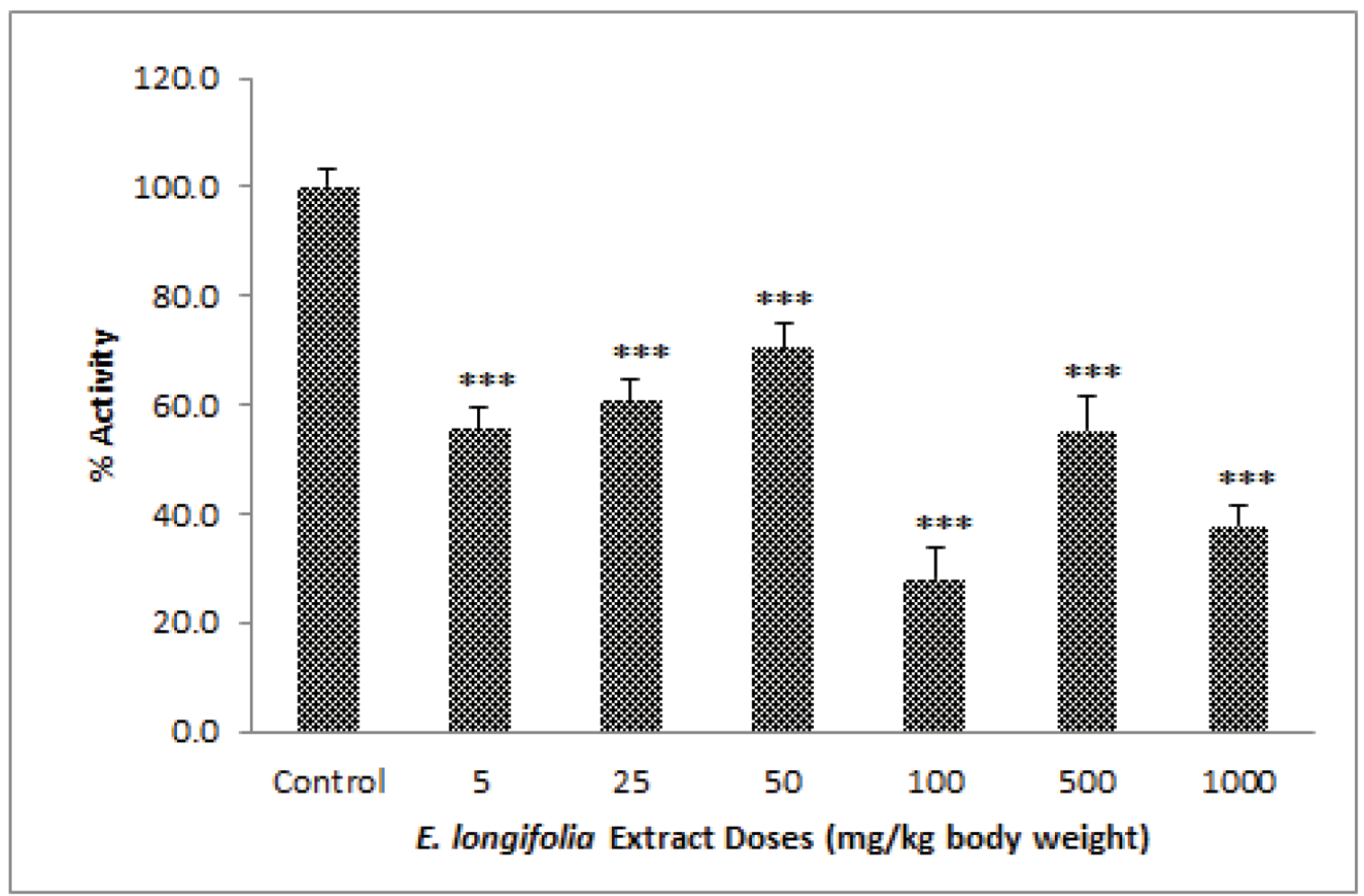

Figure 2. ELE effect on UGT activity in rat liver microsomes of treated groups (at a dose from 5 to $1,000 \mathrm{mg} / \mathrm{kg}$ b.w.) for 1-day treatment, $* \mathrm{p}<0.05, * * \mathrm{p}<0.01,{ }^{* * *} \mathrm{p}<0.001$ was significantly different if compared to control group.

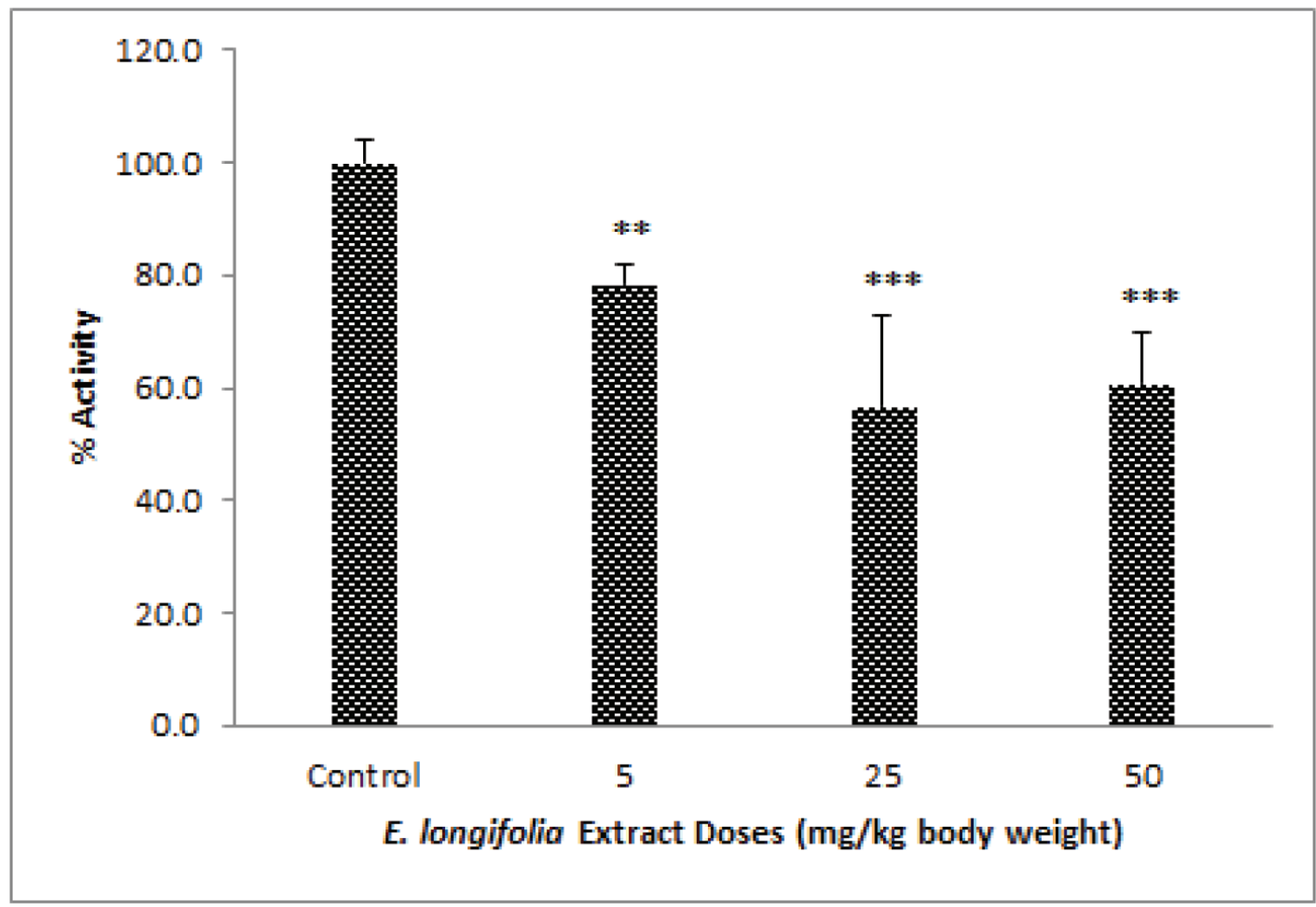

Figure 3. ELE effect on UGT activity in rat liver microsomes of ELE treated groups after 14 days oral treatment at doses 5,25 , and $50 \mathrm{mg} /$ kg b.w., ${ }^{*} \mathrm{p}<0.05,{ }^{* *} \mathrm{p}<0.01,{ }^{* * *} \mathrm{p}<0.001$ was significantly different when compared to control group. 
paniculata and $O$. stamineus had an inhibition effect on some human UGT isoforms. Orthosiphon stamineus extract showed a strong inhibitory effect, especially on UGT1A7, UGT1A1, UGT1A6, and UGT1A8. Andrographis paniculata has a higher inhibitor effect as compared to $O$. stamineus for all the isoforms used in the study: UGT1A1, UGT1A6, UGT1A3, UGT1A7, UGT1A10, UGT1A8, and UGT2B7. These findings support the potential for drug-herbal interactions (Ismail et al., 2010).

Glucuronidation that involves the UGT enzymerepresents the major route of sugar conjugation and own the important role in metabolism both for drug or xenobiotic. Glucuronide formation can occur with a variety of different substrates. Generally, the synthesis of carbamoyl, carbonyl, carboxyl, ester, ether, nitrogen, and sulfuryl glucuronides will lead to an increase in their polarity and aqueous solubility, and therefore suitability for excretion (Burchell, 1999; Mulder et al., 1990; Wingard et al., 1991). Since E. longifolia extract influenced UGT activity for both in vitro and in vivo, this requires attention, especially for long-term usage. Thus, induction or inhibition of UGT activity by another compound may influence a drug's therapeutic effect or even generate toxicity.

\section{CONCLUSION}

ELE can significantly $(p<0.05)$ reduce the UGT enzyme activity both in in vivo and in vitro studies, but ELE had a lower potency than $\mathrm{Na}$ diclofenac as a positive control. The IC-50 value of ELE was $0.74 \mu \mathrm{g} / \mathrm{ml}$, while the Na-diclofenac had an IC-50 of $0.17 \mu \mathrm{g} / \mathrm{ml}$. The $\mathrm{IC}_{50}$ for both acute and sub-acute studies cannot be defined.

\section{ACKNOWLEDGMENT}

The authors would like to thank the IRPA grant number 1001/PFARMASI/813006, School of Pharmaceutical Sciences, Universiti Sains Malaysia which has supported this research project.

\section{CONFLICT OF INTEREST}

Authors declare that there are no conflict of interest.

\section{REFERENCES}

Barnes PM, Bloom B, Nahin RL. Complementary and alternative medicine use among adults and children: United States, 2007. Natl Health Stat Reports, 2008; 12:1-24.

Bhattaram VA, Graefe U, Kohlert C, Veit M, Derendorf H. Pharmacokinetics and bioavailability of herbal medicinal products. Phytomedicine, 2002; 9(3):1-33.

Bock KW, Kohle C. Coordinate regulation of drug metabolism by xenobiotic nuclear receptors: UGTs acting together with CYPs and glucuronide transporters. Drug Metab Rev, 2004; 36(3-4):595-615.

Brazier NC, Levine MAH. Drug-herb interaction among commonly used conventional medicines: a compendium for health care professionals. Am J Ther, 2003; 10:163-9.

Burchell B. Transformation reactions: Glucuronidation. In Woolf TF (ed.). Handbook of drug metabolism, Marcel Dekker Inc, New York, NY, 1999.

Bussmann RW, Sharon D. Markets, healers, vendors, collectors: the sustainability of medicinal plant use in northern Peru. Mt Res Dev, 2009; 29(2):128-34.

Chan KL, Choo CY, Morita H, Itokawa H. High performance liquid chromatography in phytomedical analysis of Eurycoma longifolia. Planta Med, 1998; 64:741-5.

Chan KL, Choo CY, Abdullah NR, Ismail Z. Antiplasmodial studies of Eurycoma longifolia Jack using the lactate dehydrogenase assay of Plasmodium falciparum. J Ethnopharmacol, 2004; 92:223-7.

Ernst E. The risk-benefit profile of commonly used herbal therapies: Ginkgo, St. John's Wort, Ginseng, Echinacea, Saw Palmetto, and Kava. Ann Intern Med, 2002; 136:42-53. $355: 134-8$

Fugh-Berman A.Herb-drug interactions. Lancet, 2000;

Han CJ. Drug metabolism and toxicity studies of Orthosiphon stamineus, Benth (Misai Kucing) in rats. Universiti Sains Malaysia, Penang, 2006.

Han CJ, Hussin AH, Ismail S. Effect of orthosiphon stamineus leaf extracts on hepatic cytochrome P450, UGT and GST activity in STZinduced diabetic rats. J Adv Sci Arts, 2009; 1(1):1-8.

Hodex P, Trefil P, Stiborova M. Flavonoids-potent and versatile biologically active compounds interacting with cytochromes P450. ChemBiol Interact, 2002; 139:1-21.

Ismail S, Hanapi NA, Halim MRA, Uchaipichat V, Mackenzie PI. Effects of Andrographis paniculata and Orthosiphon stamineus extracts on the glucuronidation of 4-methylumbelliferone in human UGT isoforms. Molecules, 2010; 15:3578-92.

Itokawa $\mathrm{H}$, Kishi E, Morita H, Takeya K. Cytotoxic quassinoids and tirucallane-type triterpene from the woods of Eurycoma longifolia Chem Pharm Bull, 1992; 40:1053-5.

Izzo AA, Ernst E. Interactions between herbal medicines and prescribed drugs: a systematic review. Drugs, 2001; 61:2163-75.

Low WY, Tan HM. Asian traditional medicine for erectile dysfunction. J Mens Health Gender, 2007; 4(3):245-50.

Kanchanapoom T, Kasai R, Chumsri P, Hiraga Y, Yamasaki K. Canthin-6-one and $\beta$-carboline alkaloids from Eurycoma harmandiana. Phytochemistry, 2001; 56:383-6.

Mahfoudh AM, Ismail N, Ismail S, Hussin A. H. In vivo exvivo assessment of Morinda citrifolia on drug metabolizing enzymes in spontaneously hypertensive rats. Pharm Biol, 2009; 47(12):1108-16.

Mills E, Cooper C, Seely D, Kanfer I. African herbal medicines in the treatment of HIV: hypoxis and Sutherlandia. An overview of evidence and pharmacology. Nutr J, 2005; 4:19.

Morita H, Kishi E, Takeya K. Itokawa H. Biphenylneolignans from wood of Eurycoma longifolia. Phytochemistry, 1992; 31:3993-5.

Morita H, Kishi E, Takeya K, Itokawa H, Iitaka Y. Highly oxygenated quassinoids from Eurycoma longifolia. Phytocemistry, 1993; 33:691-6

Mulder GJ, Coughtrie MWH, Burchell B. Glucuronidation, conjugation reactions. In: Mulder GJ (ed.). Drug metabolism: an integrated approach, Taylor Francis, London, UK, pp 51-105, 1990.

Newall CA, Anderson LA, Phillipson JD. Herbal medicines. A guide for health-care professionals. 1st edition, The Pharmaceutical Press, London, UK, 1996.

Purwantiningsih, Hussin AH, Chan KL. Phase I drug metabolism study of the standardised extract of Eurycoma longifolia (TAF-273) in rat hepatocytes. Int J Pharm Pharm Sci, 2010; 2:147-52.

Purwantiningsih, Hussin AH, Chan KL. Herb-drug interaction study of Eurycoma longifolia extract (TAF-273) on antidiabetic drug (Rosiglitazone) metabolism. Asian J Pharm Clin Res, 2011; 4(2):88-92.

Purwantiningsih, Hussin AH, Chan KL. Sex-related alterations of aminopyrine metabolism by standardised extract of Eurycoma longifolia (TAF-273). Acta Aliment Hung, 2012: 41(3):316-26.

Purwantiningsih, Hussin AH, Chan KL, Ismail S. Inhibitory effect of Eurycoma longifolia extract and eurycomanone on human cytochrome P450 isoforms. Int J Pharm Pharm Sci, 2014; 6(6) $441-4$

Purwantiningsih, Hussin AH, Chan KL. Effect of standardized Eurycoma longifolia extract on rosiglitazone metabolism in the old normal male rat hepatocytes: a mechanism study. Int J Pharm Pharm Sci, 2015; $7(2): 80-3$

Saxena A, Tripathi KP, Roy S, Khan F, Sharma A. Pharmacovigilance: effects of herbal components on human drugs interactions involving Cytochrome P450. Bioinformation, 2008; 3(5):198-204. 
Van-Andel TR, Myren B, Van-Onselen SJ. Ghana's herbal market. J Ethnopharmacol, 2012; 140(2):368-78.

Van-Andel T, Carvalheiro LG. Why urban citizens in developing countries use traditional medicines: the case of Suriname. Evid Based Complementary Altern Med, 2013; Article ID:687-197:1-13.

Wingard LBJ, Brody TM, Larner J, Schwartz A. Pharmacodynamics. In: Kist K, Steinborn E, Salway J (eds.). Human pharmacology, molecular-to-clinical, Mosby Year Book Inc, St. Louis, MO, pp 42-5, 1991.

Zhang L, Wang Y, Zou P, Pan X, Zhang H, Chen W. Advances in clinical pharmacokinetics of herbal medicines. US-China Med Sci, 2005; 2:59-72.

Zhou SF, Gao YH, Wen QJ, Huang M, Xu AL, Paxton JW Interactions of herbs with cytochrome P450. Drug Metab Rev, 2003; 35: $35-98$.
Zhou S, Chan E, Pan SQ, Huang M, Lee EJ. Pharmacokinetic interactions of drugs with St John's wort. J Psychopharmacol, 2004; $18: 262-76$

How to cite this article:

Purwantiningsih $\mathrm{P}$, Hussin $\mathrm{AH}$, Ismail $\mathrm{S}$, Chan KL. In vitro and in vivo effect of Eurycoma longifolia root extract on UDP-glucuronosyltransferase activity. J Appl Pharm Sci, 2019; 9(09):077-083. 